\title{
AESTHETIC ARGUMENT AND PERCEPTUAL PERSUASION
}

\author{
RICHARD SHUSTERMAN \\ Ben Gurion University \\ of the Negev
}

One of the areas of aesthetics in which Wittgenstein's influence has been both positive and very powerful concerns the nature of aesthetic argument and in particular critical reasoning. Around this issue some of his most pervasive and influential aesthetic views may be focused and brought together. Moreover, it is on this issue that Wittgenstein's remarks on aesthetics, generally so sketchy and loosely organized, are comparatively detailed and sustained, and come close to constituting a real theory. Certainly, despite Wittgenstein's own notorious injunction against philosophy's advancing any kind of a theory, many contemporary aestheticians have seen or inferred an intriguingly original theory of aesthetic or critical argument from Wittgenstein's account of such argument in his lectures on aesthethics.1

In this paper after tracing three important themes of Witt-

1 Though Wittgenstein makes some pointed remarks presenting a mystical, transcendental aesthetic in the early Notebooks: 1914 -1916 (Oxford: Blackwell, 1961 ) and the Tractatus Logico.Philosophicus (London: Routledge, 1922), it is his later philosophy which has proven so influential in the theory of aesthetic argument. My discussion of Wittgenstein will therefore concentrate on his later phase and will be based chiefly on his Philosophical Investigations, 2nd ed. (0xford: Blackwell, 1958), hereafter PI, and on his lectures on aesthetics in 1932-33 and in the summer of 1938. A report of the former lectures can be found in G.E. Moore, "Wittgenstein's Lectures in 1930-33", repr. in Moore's Philosophical Papers (London: Allen and Unwin, 1959), pp. 252-324. The 1938 lectures have been transcribed from students' notes and published as part of Wittgenstein's Lectures and Conversations on Aesthetics, Psychology, and Religious Belief, edited by C. Barrett (Oxford: Blackwell, 1970), pp. 140. For Wittgenstein's injunction against thcory, see $P I \S 109$. 
genstein's aesthetics that induced him to seek a new account of aesthetic argument, I shall examine the account he offered and the popular contemporary theory of aesthetic argument into which it has evolved. However, I shall also consider some problems with this theory and shall finally suggest that it is not only wrong but inconsistent with the very doctrines that helped engender it.

The first of the three themes that induced Wittgenstein to offer a new account of aesthetic argument might be called the radical indeterminacy of aesthetic concepts. This influential and perhaps all too familiar theme is a straightforward application in aesthetics of Wittgenstein's general and seminal doctrine of the indeterminacy of ordinary concepts, and his insistence that despite their blurred edges, vague and flexible boundaries, and lack of determinate essences, these concepts are nonetheless usable, adequate, and legitimate. ${ }^{2}$ However, Wittgenstein goes on to assert that it is particularly wrongheaded to seek or expect precise boundaries and exact definitions for the especially blurred concepts of aesthetics, since such precise definition cannot by its very nature be faithful to the vagueness of the concept it is supposed to represent. "Won't it become a hopeless task to draw a sharp pictures corresponding to the blurred one?... And this is the position you are in if you look for definitions corresponding to our concepts in aesthetics or ethics." $(P I, 77)$

The thesis of the radical indeterminacy of aesthetic concepts might induce one to seek a new account of aesthetic argument, since it severely threatens the adequacy of the most popular traditional form of aesthetic argument, deductive argument based on universal premises supplied by essentialist definitions of aesthetic concepts. To illustrate this more clearly, we can roughly distinguish aesthetic concepts into two general kinds,

2 See $P I$, para. 66-71. Wittgenstein indeed suggests that a concept's vagueness and flexibility often make it more useful (para. 71). 
both of which have traditionally generated aesthetic arguments of a deductive form.

First, there are what I shall call artistic concepts which include genre concepts (like "sonnet", "epic", "symphony", "comedy"), style or period concepts (like "gothic", "baroque", "cubist") and also the archetype of all artistic concepts - the concept of art itself. We may distinguish from these artistic concepts another kind of aesthetic concepts, which cut across genre, period, and style distinctions, and which apply not only to art but to other realms of aesthetic appreciation. These concepts, which I shall dub aesthetic quality concepts, include such terms as "vivid", "delicate", "unified", awkward", "lifeless", and, of course, the paradigmatically aesthetic binary opposites "beautiful" and "ugly"; and they seem further distinguishable from artistic concepts by their characteristic evaluative colouring. ${ }^{3}$ For all our love of the comedy and the baroque, the description of a work as a baroque comedy has very little evaluative import compared to its description as vivid and unified.

However, this is not to say that what we have called artistic concepts do not function in evaluation. Indeed, one of criticism's oldest and most widely accepted forms of evaluative argument is criticism by defining essence or rules of genre. The argument is deductive, premised on the definition of the given genre (or, more generally, artistic concept). The necessary elements or properties which define the genre (e.g., those of Aristotle's definition of tragedy) also define what is required for a paradigmatic or excellent example of the genre and thus become necessary and sufficient criteria which define success or excellence in the genre. The basic underlying idea here, as Collingwood later articulated it, is that "the definition of any given kind of thing is also the

3 The special logic of this second group of aesthetic concepts has been very much discussed since F. Sibley's seminal treatment of them in "Aesthetic Concepts", repr. in J. Margolis (ed.), Philosophy Looks at the Arts, 2nd ed. (Philadelphia: Temple University Press, 1978), pp. 64-87, which also includes a brief bibliography of further work on this topic, p. 115. 
definition of a good thing of that kind".4 Thus, if a proper (or good exemplar of) tragedy requires properties $p_{1}-p_{n}$, and if work $W$ achieves these properties, then it would follow that work $W$ is a good tragedy.

Since so much evaluative argument in criticism has been regarded as having this deductive form, 5 relying ultimately on the definition of artistic concepts, the correct definition of such concepts (including that of art itself) has naturally been assumed to be of vital importance, and thus has traditionally been among the major aims and interests of aestheticians. The assumption had always been, of course, that there must be a determinate essence of each artistic concept, for otherwise how could we use and understand our artistic terms? However, Wittgenstein, by showing that our concepts need not have clear, fixed, and definite essences in order to be usable and adequate, and by further insisting that aesthetic concepts are especially vague and flexible and thus inherently resistant and unsuitable to essentialist definition, has shaken this assumption and with it much of the promise and attraction of deductive aesthetic argument based on essentialist definitions of genre, style, or art in general.

Wittgenstein's theme of the radical indeterminacy of aesthetic concepts has had much the same effect with respect to concepts of the second kind, such as 'beauty', 'sublimity', etc. The concept of beauty, like that of art, has since ancient times been the target of countless attempts at definition. Again, as with art and many of its genre concepts, these definitions were often sought and thought to provide criteria for evaluation, to provide the categorical, universal premise in a deductive argument justifying particular judgments of aesthetic value. If beauty is defined as constituted by property $B$, then whatever has $B$ is beautiful; and thus, if a particular artwork or natural phenomenon possesses $B$, we can conclude

4 R.G. Collingwood, The Principles of Art (Oxford: University Press, 1958), p. 280.

5 For some examples of such argument based on the definition of the genre of tragedy, see M. Weitz, Hamlet and the Philosophy of Literary Criticism (London: Faber, 1972), pp. 156-186, 272-275. 
that it is beautiful. However, definitions of beauty have been no more successful than definitions of art; for beauty too is a concept whose content, borders, and application are not only vague and flexible, but are essentially contested by its many users. Wittgenstein realized this and, according to Moore, "seemed to hold definitely that there is nothing in common in our different uses of the word 'beautiful', saying that we use it 'in a hundred different games' - that, e.g., the beauty of a face is something different from the beauty of a chair or a flower or the binding of a book." 6 Thus, by challenging the assumption that concepts need clear boundaries and common essences to be functional, and by pointing to the apparent lack of these features in the concept of beauty, Wittgenstein destroyed the aesthetician's faith that there must be a correct definition of beauty, somewhere at the end of the rainbow, which once found could serve as a touchstone for critical evaluation and as an ultimate justificatory premise for deductive evaluative argument. There was thus room and reason for an alternative account of aesthetic argument.

2. A second important Wittgensteinian theme which helped generate a new account of aesthetic argument is the logical plurality of aesthetic discourse. This theme has two aspects: (a) recognition of the logical variety of aesthetic statements and (b) recognition of the plurality of aesthetic frameworks. The first is a straightforward application in aesthetics of Wittgenstein's famous doctrine that language performs a variety of logically different tasks. It is not a monolithic, uniform instrument, but, in Wittgenstein's image, more of a tool box. The functions of sentences and indeed the functions of words are at least as different as the functions of different tools. "Think of the tools in a toolbox: there is a hammer, pliers, a saw, a screw-driver, a rule, a glue-pot, glue, nails and screws. -The functions of words are as diverse as the functions of these objects." $(P I, 11)$

According to Wittgenstein, one of the major sources of

6 Moore, p. 313. 
errors in philosophy is the assimilation of the many different functions of diverse words into one single paradigmatic type. It is an altogether natural but altogether pernicious tendency to concentrate one's attention wholly on one or on one type of word and to see it as representing all words of a certain kind or area of inquiry, and thus to assume that by determining the meaning of this word we can essentially resolve the entire area of inquiry. In aesthetic evaluation this error is manifested by the aesthetician's excessive attention to the predicate "beautiful". As we noted earlier, intense concentration has been directed at the definition of the beautiful, on the assumption that an adequate definition or understanding of it would solve all important questions of aesthetic evaluation.

However, Wittgenstein insists, this could not be further from the truth. For, in the first place, if we look at our evaluative judgments in criticism, we find that we hardly use the word "beautiful" at all, but more often words like "right" and "wrong". Indeed, we use a variety of kinds of predicates and expressions.

It is remarkable that in real life, when aesthetic judgements are made, aesthetic adjectives such as 'beautiful', 'fine', etcetera, play hardly any role at all. Are aesthetic adjectives used in a musical criticism? You say: 'Look at this transition', or... 'The passage here is incoherent'. Or you say, in a poetical criticism, ... 'His use of images is precise'. The words you use are more akin to 'right' and 'correct' (as these words are used in ordinary speech) than to 'beautiful' and 'lovely'.7

Secondly, not only are there different kinds of aesthetic predicates, but often the very same aesthetic predicate can be used in logically different ways. For instance, though "beautiful" and "lovely" are most often used as interjections and

7 Lectures and Conversations, p. 3. 
expressions of approval, they can also be used descriptively. We can describe the character (as opposed to the value) of a picture as beautiful or lovely. We might even describe certain works of art, e.g., Kitsch, as too beautiful or too lovely. Here these aesthetic predicates are surely functioning very differently from their typical use as (non-descriptive) expressions of approval, e.g., "How beautiful!", "Lovely", etcétera.

Thirdly, and this is very central to Wittgenstein's thought, whatever words we use in evaluating art, the main thing that gives meaning to our judgements is not the words themselves but the complex cultural and aesthetic context, the occasions and activities, in which these words are used. To understand what an aesthetic judgment is or means, says Wittgenstein, requires "concentrating, not on the words 'good' or 'beautiful', which are entirely uncharacteristic, ... but on the occasions on which they are said - on the enormously complicated situation in which the aesthetic expression has a place, in which the expression itself has almost a negligible place."8 Thus, not only are there many different terms of judgment in criticism, having logically different functions, but even the very same term can have different functions, and hence the significance of an aesthetic judgment is not really in the words uttered but more in the cultural and aesthetic context in which it appears, in its role in our "ways of living" with art.9

However, we then face the second aspect of this theme of pluralism: there is in our culture a variety of aesthetic contexts or frameworks, which often have different aims. Recognizing that a note is wrong is not like recognizing that a particular movement is triumphant; appreciating the right length of a sonnet (or of a dress) is something very different from appreciating the sublimity of a tragedy. And, to turn from evaluation to interpretation, the literal explanation of, say, a religious poem is something very different from a psychoanalytical interpretation of it. As Wittgenstein says,

8 Ibid., p. 2.

9 Ibid., p. 11. "In order to get clear about aesthetic words you have to describe ways of living." 
"The games played ... are utterly different. The explanations could in a sense be contradictory and yet both be correct."10

3. Moreover, as Wittgenstein emphasizes, plurality abounds not only synchronically but diachronically. Different periods produce different cultures, and thus the aesthetic judgments of, say, the Middle Ages would be very different in meaning from those of today, even if the very same words were used. As Wittgenstein insists :

The words we call expressions of aesthetic judgement play a very complicated role, but a very definite role in what we call a culture of a period. To describe their use or to describe what you mean by a cultured taste you have to describe a culture. What we now call a cultured taste perhaps didn't exist in the Middle Ages. An entirely different game is played in different ages. ${ }^{11}$

This historical pluralism or contextualism directly involves us in the third Wittgensteinian doctrine which I wish to treat as contributing to the generation of a new account of aesthetic argument: the essential cultural historicity of art and aesthetic appreciation. As the previous quotation indicates, Wittgenstein regarded the notions of beauty, art, and aesthetic appreciation not as things necessary, unchanging, and independent of social change and human history, but rather as products of human culture and history which could have been otherwise (e.g., could have had different standards, used different media, etcetera) and which change as society changes, even if sometimes imperceptibly. Our aesthetic concepts are inextricably bound up in our forms of life, in ways of living which change over history through social, technical, and even theoretical developments. In this aspect of his aesthetics, Wittgenstein paved the way for the historical, social, and institutional theories of art which dominate contemporary

10 lbid., p. 23.

11 lbid., p. 8. 
analytic aesthetics in the work of Wollheim, Danto, and Dickie. 12

But how do these second and third Wittgensteinian themes lead to a new account of the nature of aesthetic argument? First, recognition that the meaning of an aesthetic predicate is not some fixed and autonomous essence, but rather changes significantly according to culture and context, has made the prospect of deriving or justifying our evaluative judgments deductively from firm unchanging definitions of such predicates seem hopelessly quixotic and misguided, since such predicates seem to have no firm or fixed meaning to be defined. The old but still glowing hope to establish aesthetic argument on a firm and certain deductive model was thus immeasurably dimmed, if not virtually extinguished.

Secondly, the flexibility and historical change of aesthetic concepts that Wittgenstein insists upon can be taken even further to question also the adequacy and legitimacy of inductive or probabilistic arguments in aesthetics. For, if the very meaning of an aesthetic predicate or expression changes with changing aesthetic, cultural, or historical context, how can we use its past applications to justify its present one. An entirely different game may be played with the expression; it may have changed its meaning and become inapplicable. If the concept of unity changes from context to context, age to age, the fact that poems lacking property $P$ were formerly correctly described as disunified gives little confidence that whatever now lacks this property will also be lacking in unity. We may be in a new context, a new game. The creative artist with his new poem may have added a new dimension to the notion of poetic unity.

In the light of the anti-inductive import of his pluralistic and contextualistic views, it is not surprising that Wittgen-

12 Sec, for example, R. Wollheim, Art and its Objects, 2nd ed. (Cambridge: University Press, 1980), pp. 159-168; A. Danto, "The Artworld", repr. in Margolis, pp. 132-144; and G. Dickie, Art and the Aesthetic: An Institutional Analysis (Ithaca: Comell University Press, 1974). See also T.J. Diffey, "On Defining 'Art' ", British Journal of Aesthetics, 19 (1979), pp. 15-23; and G. MeFee, "The Historicity of Art", Journal of Aesthetics and Art Criticism, 38 (1940), pp. 307-324. 
stein comes out very vehemently against probabilistic and statistical explanation in aesthetics. One does not demonstrate the unity of a symphony by the evidence that fifty million Frenchmen can't be wrong. Wittgenstein's scornful attack on the idea of statistical and inductive explanation in aesthetics was perhaps the deathblow to the hope (of I.A. Richards and others) of transforming aesthetics into a psychological science. 13

If Wittgenstein's doctrines of the radical indeterminacy of aesthetic concepts and the logical plurality and essential historicity of aesthetic judgment work to undermine the charm and credibility of both deductive and inductive models of aesthetic argument, his lecture remarks on aesthetics do indeed suggest an intriguingly original and influential account of the nature of such reasoning. G.E. Moore recounts these remarks as follows:

"Reasons, he said, in Aesthetics are 'of the nature of further descriptions': e.g., you can make a person see what Brahms was driving at by showing him lots of different pieces of Brahms, or by comparing him with a contemporary author; and that all Aesthetics does is 'to draw your attention to a thing', to 'place things side by side'. He said that if, by giving 'reasons' of this sort, you make another person 'see what you see' but it still doesn't appeal to him, that is 'an end' of the discussion". 14

As I have argued elsewhere, this view of aesthetic argument may be characterized as perceptualist rather than logical or

13 Wittgenstein could hardly be more derisive about psychological aesthetics: "People often say that aesthetics is a branch of psychology. The idea is that once we are more advanced, everything - all the mysteries of Art - will be understood by psychological experiments. Exceedingly stupid as the idea is, this is roughly it." (Lectures and Conversations, p. 17).

"People still have the idea that psychology is one day going to explain all our aesthetic judgements, and they mean experimental psychology. This is very funny - very funny indeed. There doesn't seem any connection between what psychologists do and any judgement about a work of art." (Ibid., p. 19).

14 Moore, p. 315. 
casual.15 In other words, the critic's reasons are regarded not as logically justifying his judgment in terms of principles or evidence in a deductive or inductive argument; nor as causally explaining or recommending it in terms of the motives or causes which engendered it. Rather the critic's reasons function as devices for focusing the reader's perception in such a way that he will see the work as the critic sees it. Perception is the proof. The critic, both in interpretation and in evaluation, is trying to get his reader to perceive the work in a certain way, and the reasons he gives are devices to induce in the reader the desired perception of the work.

Moreover, it is only the giving of these reasons, and not the reasons themselves, which may be the cause of the reader's accepting the critic's judgment; for following the reasons given may help the reader to focus on the work so that he sees it as the critic does. This difference between the citing of reasons and the reasons cited can be explained by the follow. ing example. Suppose that in justifying his judgment of a love poem as harsh and crude, a critic cites the predominance of voiced plosives and the similarity of its imagery to some bawdy song. Neither the plosives nor the similarity may themselves be what causes the reader to perceive the poem as harsh and crude; but the act of citing these reasons may focus attention on the work in such a way that the perception of harshness and crudity is induced, and the critical judgment is thus accepted.

Wittgenstein's idea that aesthetic argument can be of an essentially perceptual character has been adopted and developed by many analytic aestheticians, and also gains support from the frequent inadequacy of reading criticism without having the work of art perceptually before us. Moreover, certainly much good criticism suits this perceptualist model of reasoning. 16

15 For a discussion of the perceptualist, logical, and causal theories of aesthetic reasons, see R. Shusterman, "The Logic of Interpretation", Philosophical Quarterly, 28 (1978), pp. 310-324; and "Evalua tive Reasoning in Criticism", Ratio, 23 (1981), pp. 141-157.

16 For examples of such criticism, see papers cited in note 15. 
Wittgenstein's lectures on aesthetics not only present aesthetic reasoning as perceptual in nature, but also as neither deductive nor inductive in form. Aesthetic arguments, it is suggested, are rather of a complex, open, and flexibly structured form, consisting of comparisons, associations, leading questions, and focusing instructions directed at an often hypothetical interlocutor, the reader. I have called this form of argument "dialectic", John Wisdom has called it "rhetoric"; 11 both terms have unfortunate associations. But whatever we call such argument, the main question is how its validity is to be assessed.

Wittgenstein's answer seems an extremely simple and programatic one: validity is success, success in inducing the desired perception of the work, if not also the desired critical verdict. He held that "aesthetic discussions were like discussions in a court of law", where the goal and criterion of success is that "what you say will appeal to the judge."18 Elsewhere, Wittgenstein suggests that the criterion for adequacy of argument and correctness of explanation is acceptance or satisfaction. "The answer in these cases is the one that satisfied you."19 "That explanation is the right one which clicks" and is accepted by one's interlocutor; "if he didn't agree, this wouldn't be the explanation."20

There is no doubt that much aesthetic argument has this dialectical or rhetorically persuasive form and is evaluated not by principles of deductive or inductive validity but rather by its power in convincing or satisfying its readers. Yet, what is especially important here is that Wittgenstein does not present this form of reasoning as an inferior, degenerate departure from rational reasoning, which reflects, as it were, the inherent irrationality of aesthetics itself. Wittgenstein rather regards this style of argument as perfectly legitimate and reasonable, and as not at all limited to the domain

17 See J. Wisdom, “A Note on Ayer's Language, Truth, and Logic" repr. in Philosophy and Psycho Analysis (Oxford: Blackwell, 1957), p. 247.

18 Moore, p. 315.

19 Lectures and Conversations, p. 18.

20 Ibid., pp. 19, 21. 
of aesthetics. It may also be found in the law courts and even in philosophy, and indeed even in some areas of science. Wittgenstein confessed that much of his own philosophical argumentation is just persuading his audience or readers to see a particular phenomenon in a particular way, much as the critic tries to persuade his readers to see a work of art in a particular way. "What I'm doing is also persuasion. If someone says 'There is not a difference', and I say "There is a difference", I am persuading; I am saying I don't want you to look at it like that." 21 Wittgenstein in fact suggests that such persuasion is also present in science. For instance, it underlies our firm and ready acceptance of the theories of Darwin and Freud, even when the grounds for their doctrines were, in strictly logical terms of confirmation, "extremely thin".22 We have been largely persuaded by the attraction of looking at things the way these theories present them.

Wittgenstein's account of aesthetic argument as perceptualist and rhetorically persuasive, as basically different in kind from deductive and inductive logic and causal explanation and thus free from their standards of validity; and his insistence that criticism shares this character with other types of reasoning (e.g., legal and philosophical) whose rationality and validity are not questioned, have had, I think, great value for critical theory. Wittgenstein's doctrines have freed criticism from the need to seek justification and legitimacy by aping (inductive or deductive) science through the construction of such allegedly systematic frameworks as that suggested by Northrop Frye or through the proposed subsumption of criticism into an accepted science like linguistics. ${ }^{23}$ Moreover, by freeing critical reasoning from bondage to deductive or inductive models, it has freed critics from the typically fruitless search for definitions on which to base deductive proof and from the often tedious accumulation of con-

21 Ibid., p. 27.

22 Ibid., pp. 26-27.

23 See N. Frye, Anatomy of Criticism (Princeton: University Press, 1957), pp. 3-29; and R. Jakobson, "Linguistics and Poetics", in T.A. Sebeok (ed), Style in Language, (Cambridge, Mass.: MIT Press, 1960), pp. 350-377. 
firmatory data demanded by strict inductive argument. The critic is thus free to get on with his critical practice without needing to provide the logical underpinnings and justification for this practice and without having to change it to meet some extrinsic logical standard. The only apparent requirement is to be convincing. This emancipatory yet quiescent achievement seems perfectly in keeping with Wittgenstein's conception of the role of philosophy. "Philosophy. . . leaves everything as it is." (PI, 124)

\section{IV}

The liberating effect of Wittgenstein's account of aesthetic argument and its apparent philosophical legitimation of critical laissez-faire and persuasion make it seem attractive in these days of plurality and controversy as to the practice or methodology of criticism. But some, on the contrary, might object that precisely this radical libertarianism makes Wittgentein's account very unattractive as a theory of aesthetic argument, for it seems to render such argument too free and unprincipled to be considered an acceptable form of reasoning at all. One could argue that the very notion of a rational form of argument requires some constraints or directions on the manner of argument, on the way it may be conducted. For if successful persuasion were indeed the sole constraint on argument, there would be no way of distinguishing the illocutionary act of arguing from the perlocutionary act of persuading.

Moreover, on many occasions, both in aesthetics and elsewhere, although we are not convinced by a given argument we can recognize it as reasonable or legitimate and assess it as superior to other, perhaps frivolous or irrational, arguments which might be advanced for the same conclusion of which the given reasonable argument failed to convince us. In other words, we seem able to assess the reasonableness or rationality of an aesthetic argument apart from its success in perceptually convincing us of its conclusion; and this again suggests 
that some principles or constraints seem to govern aesthetic argumentation, however vague, liberal, and flexible these constraints may be. This might also be made clear by imagining ways where a critic might succeed in getting an interlocutor to see something his way but which would not be regarded as constituting good or even legitimate argument for his view, e.g., hypnosis, threats, or suggestion through drugs. More generally, we want to allow for cases where persuasion is achieved improperly or illegitimately, where one could be but should not be persuaded.

Thus, the extreme libertarian view that in aesthetic argument anything goes provided it evokes perceptual assent is fundamentally problematic, and Wittgenstein' apparent acceptance of such freedom would seem to vitiate his account of aesthetic reasoning. However, I believe this difficulty may be avoided by arguing that the Wittgensteinian account's apparent acceptance of total freedom is only apparent and not real. First, though Wittgenstein clearly suggests that satisfaction or successful persuasion is a criterion of an adequate aesthetic argument (or a correct aesthetic explanation), he never explicitly maintains that satisfaction or success is the only constrain on the legitimacy of an aesthetic argument. In other words, the Wittgensteinian could maintain that simply to qualify as a legitimate aesthetic argument certain constraints or requirements must be observed, and only then would satisfaction or successful persuasion entail adequacy or validity of argument. One might put this another way by reading such constraints into the very notion of an aesthetic argument satisfying or persuading, i.e., such satisfaction or persuasion is not mere assent, but assent under certain constraints, through certain acceptable means.

Moreover, if we examine Wittgenstein's remarks more closely we see that they not only allow the possibility of constraints on how perceptual persuasion is to be achieved but they also give a definite indication as to how these constraints or requirements should be conceived. They are to be construed as the diverse vague, flexible, and largely unformulated rules and principles which govern the various language- 
games and procedures that are entrenched in our forms of living with art. Aesthetic arguments of perceptual persuasion involve a great many conventional procedures which are shared by those competent in aesthetic appreciation within the given culture. Wittgenstein, characteristically, does not try to enumerate or classify these conventional procedures for perceptual persuasion (Sibley distinguishes seven), ${ }^{24}$ but he does indicate by his examples of perceptual reasons that such reasons fall centrally in the domain of conventional critical practices, which Eliot and others have classified under the two general principles of comparison and analysis. 25

Aesthetic arguments are thus limited by the languagegames which constitute our aesthetic forms of life. The freedom that Wittgenstein allows the critic is only within these limits. But this is not to say that aesthetic argument is fixedly limited to any given boundaries, for that would be to assume that our aesthetic language-games or forms of life are fixed and cannot be modified or supplemented. This, by Wittgenstein's own historicist account, is patently wrong. Our forms of aesthetic appreciation and argument can change (and have changed) with time.

However, Wittgenstein's recognition of the flexible, historicist, and conventional character of aesthetic argument should not be interpreted (like Slater ${ }^{26}$ has recently interpreted it) as an aesthetic subjectivism where reasons are given but can not "establish conclusions" since their coercive power rests only on conventional practices which are contingent rather than necessary and have no further metaphysical grounding. Here one must reply that for Wittgenstein there need not be (nor perhaps is there) anything deeper and metaphysical on which to base human conventions and practices. Conventions constitute the bedrock of our language, and the world and experience it informs. As he remarks in

24 "Aesthetic Concepts", pp. 79-81.

25 See T.S. Eliot, "The Function of Criticism", in F. Kermode (ed.), Selected Prose of T.S. Eliot (London: Faber, 1975 , p. 75.

26 H. Slater, "Wittgenstein's Acsthetics", British Journal of Aesthetics, 23 (1983), pp. 34-37. 
The Blue Book: "Here we strike rock bottom, that is we have come down to conventions." 27

Thus, the charge of vitiating radical anomie in Wittgenstein's account of perceptualist argument can be readily countered, and does not therefore preclude this account's constituting an acceptable theory of the general nature of aesthetic argument. However, so construing it may, as we shall soon see, raise far more serious problems.

In any case, and whether or not Wittgenstein so intended it, his account of (some) aesthetic reasoning as perceptual and persuasive in nature has been adopted by many analytic aestheticians and transformed into a theory of what all aesthetic argument essentially is or should be, a theory that all valid or effective aesthetic argument ultimately is and must be of this perceptually persuasive kind. In other words, not only does it maintain that (good) aesthetic argument need not be deductive or inductive in form and that aesthetic reasons need not function as general principles or evidence logically supporting an aesthetic judgment, but also and more radically that (good) aesthetic argument cannot be of such deductive or inductive character nor can its reasons be seen as having a logical, evidential, or even strictly causal role. Aesthetic argument can be nothing else than perceptual persuasion.

Thus Stuart Hampshire rejects the idea of any "general principles" in aesthetic reasoning and insists that the critic's role is only "to direct attention"; "the point is to bring people to see these features, and not simply to lead them to say: 'That's good'.'28 Again, as with Wittgenstein, the criterion of success is getting someone to see: "if one has been brought to see what there is to be seen in the object, the purpose of discussion is achieved."29 Margaret Macdonald likewise

27 L. Wittgenstein, The Blue and Brown Books (New York: Harper, 1958), p. 24. For a detailed discussion of the problem of treating convention as something essentially superficial or arbitrary, see my paper "Convention: Variations on a Theme", forthcoming in Philosophical Investigations.

23 S. Hampshire, "Logic and Apprecia tion", repr. in W. Elton (ed.), Aesthetics and Language (Oxford: Black well, 1967), pp. 169, 166.

29 Ibid., p. 165. 
asserts that reasoning about aesthetic judgments is "unlike. . . deductive and inductive inference" and that "to justify such a verdict is not to give general criteria as 'reasons' but to. .. 'show' the value".,30 For her, as for Frank Sibley, the critic's reasons serve as "a kind of key to grasping or seeing", where the goal is to get "his audience to see what he sees". 31 In a similar vein, Arnold Isenberg comes out against deductive and inductive justifications of aesthetic judgments and maintains that the critic's reasons not only function perceptually but that their very meaning is perceptual in character: "the critic's meaning is 'filled in', 'rounded out', or 'completed' by the act of perception", which is necessary for the simple understanding of the reason he cites. Again, also with Isenberg, the goal of aesthetic argument is "to induce a sameness of vision, of experienced content", which "may or may not be followed by agreement. . . in identical value judgments." 32

It seems, then, that Wittgenstein's portrayal of aesthetic argument as perceptually persuasive and not necessarily deductively or inductively logical has evolved into a theory asserting that all valid aesthetic arguments is of this perceptually persuasive kind and that deductive and inductive models of critical reasoning are simply wrong (i.e., not reflective of accepted critical practice) and fundamentally wrongheaded. And though the first view is clearly correct, the second seems rather dubious. Yet it is very natural and dangerously easy to slide from one view to the other. ${ }^{33}$ For

30 M. Macdonald, "Some Distinctive Features of Arguments Used in Criticism of the Arts", repr. in Elton, pp. 121, 129.

31 "Aesthetic Concepts", pp. 79, 80.

32 A. Isenberg, "Critical Communication", repr. in Elton, pp. 137-138. John Casey, who draws heavily on Wittgenstein and describes critical argument as "persuading. . . to see. . . in a particular way", goes even further than Isenberg (and Wittgenstein) by maintaining that sameness of vision entails identical value judgements. See J. Casey, The Language of Criticism (London: Methuen, 1966), pp. 172-173.

33 We can see this slide quite clearly in the following passage from Casey: "The idea that particular judgements, if they are to be objective, have to be deduced from general principles, or entailed by general descriptions, is the fundamental fallacy. To defend a judgement of a poem one has to go on describing it, relating it to other poems and so on, until the person one is trying to convince is 
when one is intent upon insisting that aesthetic arguments need not be deductively or inductively logical but can be instead (and often are quite effectively) perceptually persuasive, one is naturally preoccupied with the presence and merit of this latter form of argument, and thus one is apt to ignore the claims and even existence of other kinds of aesthetic argument. One falls victim to what Wittgenstein diagnosed as "a main cause of philosophical disease - a one-sided diet: one nourishes one's thinking with only one kind of example." $(P I, 593)$

Thus, despite its current popularity and Wittgensteinian roots, I am reluctant either to accept or to attribute to Wittgenstein the theory that aesthetic argument essentially is or should be perceptual persuasion; and in the remainder of this paper I shall argue that this theory is not only wrong but fundamentally inconsistent with the very themes which helped generate Wittgenstein's perceptual-persuasive account of aesthetic argument. Let us take the second charge first.

The three Wittgensteinian themes we earlier considered all reflect and indeed insist upon critical pluralism. First, aesthetic concepts cannot be precisely and exhaustively defined because they have a plurality of different uses and are governed by flexible and changing conditions of application. Secondly, the diverse expressions used in criticism are used to perform a variety of logically different roles and indeed may change their roles and meaning in different contexts. Finally, since the whole notion of aesthetic appreciation and judgment depends on our complex forms of life which can and do change over time, the fact that at a particular time aesthetic concepts are applied in a particular way and aesthetic judgments are made or supported in a particular way does not mean that they always are or need be applied, made, or supported in these particular ways.

satisfied. There are no general laws which will take the place of this". (Ibid., p. 138, my italics.)

In opposing the fallacy that objective aesthetic argument must be deductive, Casey falls into the fallacy that such reasoning cannot be deductive or nonperceptually persuasive. 
If we take this pluralism seriously, as I think we should, we cannot simply rule out deductive and inductive models of aesthetic argument as intrinsically wrong and illegitimate. We cannot argue, from the condition of contemporary criticism with its confusion, controversy, and lack of faith as to general principles and definitions, that deductive argument from general principles or shared definitions is never possible in criticism nor could ever have been successfully practiced since such principles or definitions are impossible to formulate or agree upon. For though they may be so today, they may not have been so in the past and may not be so again in the future. In Aristotle's time there may well have been a shared essence of tragedy to define. In Johnson's time there seem to have been general principles and standards of criticism which were commonly held and firmly established.34 We cannot simply deny this on the basis of the state of criticism today. What justification can we have for asserting (as some theorists have) that although certain critics claim to be and seem to be arguing deductively from general principles and definitions, they cannot really be doing so since "critical evaluation. . . cannot be true (or false) deductive argument" there being no satisfactory definitions or irresistibly conclusive standards to base such argument?35 For,even if the definitions and standards on which critics have based their deductions seem wrong to us (in fact even if they are and were wrong), this cannot negate the fact that their arguments were deductive and indeed deductively valid. To claim that aesthetic argument never was nor could be deductive is to deny that different critical games may be played at different times, which is precisely what Wittgenstein laboured so hard to

34 T.S. Eliot, "Johnson as Critic and Poet", in Un Poetry and Poets (London: Faber, 1957), pp. 162-193.

35 Weitz, p. 275. Casey (p. 138) also argues that adequate general "standards. . neither can exist, nor can have the function" of convincing prernises in a deductive argument. Weitz, besides questioning the conclusiveness of evaluative principles in criticism, also rules out evaluative deduction on the basis of an argument which commits the fallacy of denying the compatibility of description and praise. For criticism of Weitz's argument, see "Evaluative Reasoning in Criticism", p. 152. 
establish. The same considerations hold against ruling out the possibility of inductive aesthetic argument, and we can point to critics of the past who seem to reason inductively. ${ }^{36}$

Moreover, even if we consider only contemporary criticism but make ourselves aware of the variety of differently functioning predicates it employs, we should realize that the theory that (good) critical reasoning can only be of the perceptually persuasive kind is far from convincing. Let us remember that criticism not only ascribes predicates like "lovely", "unified", and "powerful", but also ascribes predicates like "important" and "original", which clearly can be and often are justified inductively through confirmatory evidence. As the contemporary critic Graham Hough maintains:

It is not really open to anyone to say 'Yes, Dante's works exist, but they are not of any importance'. This is contradicted by a large body of indisputable evidence. And it would be a very strange position to hold that Dante's fame and influence were no evidence of literary merit.37

Here we should remember that not only ascription of merit but also ascription of importance itself can constitute critical evaluation.

Thus, the fact that arguments of a deductive or inductive form have been and are successfully employed by established critics clearly seems to render untenable the theory that all valid aesthetic argument is or must be that of perceptual persuasion. To maintain that these other arguments cannot be valid or effective, despite their entrenched acceptance in critical practice (which perhaps in itself constitutes their justification), merely on the grounds that they are not perceptual persuasion and that perceptual persuasion is the only valid or truly effective form of aesthetic argument is simply to beg the whole question, and to do so in a way wholly in-

36 See Ibid., pp. 143, 151.

37 G. Hough, An Essay on Criticism (New York: Norton, 1966), p. 176. 
consistent with the aesthetic pluralism inherent in Wittgenstein's aesthetics.

Embracing this pluralism allows us to accept Wittgenstein's account of aesthetic argument as perceptual persuasion, while rejecting the erroneous general theory which evolved from it. Wittgenstein's account is to be taken as describing one form of aesthetic argument or explanation, highlighting one of many language-games in aesthetic appreciation, one which is widespread and important, but had so far escaped philosophical attention. His highlighting and justifying this one game, should not blind us to the existence and efficacy of other games involved in the justification and explanation of aesthetic judgments; and as Wittgenstein so insistently reminds us, these games are extremely numerous and diverse.

Wittgenstein correctly diagnoses "the craving for simplicity" 38 as the reason we find monistic or essentialistic theories so attractive in aesthetics. But we must resist this craving in the name of truth and in the face of a plurality of aesthetic language-games which serve a variety of aims and employ a diversity of forms of argument. ${ }^{39}$

33 Lectures and Conversations, p. 36. Wittgenstein adds: "If your explanation is complicated, it is disagreeable, especially if you don't have strong feelings about the thing itself." (Ibid.)

39 I have analyzed and classified some of these different language-games in "The Logic of Interpretation" and "Evaluative Reasoning in Criticism", and also in "The Logic of Evaluation", Philosophical Quarterly, 30 (1980), pp. 327-341, and "Four Problems in Aesthetics", International Philosophical Quarterly, 22 (1982), pp. $21-33$. 
RESUMEN

La influencia de Wittgenstein sobre la estética se siente, con particular fuerza, con relación al argumento estético, nos dice el Dr. Shusterman, quien engloba la contribución wittgensteiniana en este campo en tres temas principales. Al primero'lo Ilama la 'radical indeterminación de los conceptos estéticos'. Los conceptos que usamos en la crítica y reflexión sobre el arte pueden ser de dos clases; artísticos: los que definen el género (sinfonía, pintura épica), estilo o período (gótico, quattrocento), o el concepto mismo de 'arte'; y estéticos: los adjetivos que califican nuestra experiencia como 'vívido', 'delicado' o el concepto de 'belleza'. La argumentación que formulamos al evaluar una obra usando conceptos 'artísticos' es deductiva; el ejemplo es la tragedia en Aristóteles, donde la definición de lo que es una tragedia lleva implícita la definición de la norma con la cual juzgar si una tragedia es buena o no. Al usar conceptos 'estéticos' en nuestra evaluación de una obra también tendemos a hacer un argumento deductivo, pues requerimos, por ejemplo, de la definición de lo grotesco, para saber si una obra cae o no dentro de esa clasificación. La crítica de Wittgenstein parte de que estas dos familias de conceptos se refieren a conceptos indeterminados, que no tienen límites definibles, ni podemos esperar que los tengan. Los conceptos estéticos dependen, y éste es el segundo tema, de la 'pluralidad lógica del discurso estético', donde Wittgenstein nos pide que consideremos a las palabras como herramientas cuyo uso es múltiple. El sentido de la palabra 'bello' depende de la función que desempeñe en un juego de lenguaje dado, así como del contexto histórico y social en el que se dé. Esto nos lleva al tercer tema, el de la 'historicidad del arte y la apreciación estética', pues el uso que se le da a las palabras en una época es distinto al que tuvo en el pasado o tendrá en el futuro.

Esta indeterminación de los conceptos estéticos desacredita la validez de los argumentos estéticos deductivos e inductivos. Para Wittgenstein, el argumento estético que desarrolla un crítico tiene la función, al no apoyarse en definiciones preestablecidas, de describir la obra de tal manera que los demás la vean como él. La percepción es la prueba final. El argumento estético, que Wisdom llama retórico y Shusterman dialéctico, busca convencer, y en esto radica su éxito. Esta forma de razonar en el arte, distinta a la deducción e inducción lógica, no es exclusiva de éste, pues se usa en el lenguaje legal en una corte y en la misma filosofía (la de Wittgenstein se proponía convencer); teorías como las de Newton y Freud se aceptan, no tanto por su respaldo lógico, sino por la atracción de ver el mundo desde su perspectiva.

Pero aceptar las sugerencias de Wittgenstein no implica rechazar los 
argumentos estéticos deductivos e inductivos como necesariamente falsos (como hace Casey), sino al contrario, y de acuerdo con la pluralidad wittgensteiniana, afirmar que la falta de principios y la multiplicidad de puntos de vista en la crítica de nuestros días exige una interpretación abierta $\dot{a}$ la Wittgenstein no implica que en otra situación histórica (p. ej. en la Grecia de Aristóteles) no se haya podido evaluar acertadamente una obra de arte mediante argumentos deductivos. De igual forma, ciertos argumentos inductivos (p. ej. afirmar que, a pesar del consenso, Dante es un mal poeta tiene que ser falso) deben tener validez, pues de lo contrario toda nuestra concepción de la cultura se vería cuestionada. Por esto, Shusterman concluye, ser fieles a lo que enseñó Wittgenstein requiere no cegarse a que la pluralidad de las funciones del lenguaje estético es aun mayor que lo que a veces estamos dispuestos a aceptar, y que nuestra posición abierta es sólo una entre varias.

[Luis Argudin] 